\title{
Effect of Nutritional Factors and Growth Conditions on Biosurfactant Production by Pseudomonas mendocina and Pseudomonas oleovorans Isolated from Oil Contaminated Soil in Jeddah City
}

\author{
Ebtihal A. Motwali ${ }^{1 *}$, Magda M. Aly², Huda A. Qari², Nuha M. Alhazmi ${ }^{1}$
}

\author{
'Department of Biology, College of Science, Univirsity of Jeddah, Jeddah, Saudi Arabia. \\ 2Department of Biology, Faculity of Science, King Abdulaziz Univirsity, Jeddah, Saudi Arabia. \\ *Correspondence to: Ebtihal A. Motwali (E-mail: ebtihalmotwali@gmail.com) \\ (Submitted: 06 September 2021 - Revised version received: 19 September 2021 - Accepted: 22 October 2021 - Published online: 26 December 2021)
}

\begin{abstract}
Objectives: The current study aimed to investigate the impact of different nutritional factors and growth conditions on biosurfactant production by bacterial isolates (EMB16 and EMB21) isolated from oil-contaminated soil samples.

Methods: Based on the used quantitative and qualitative screening method in current study, the selected bacterial isolates showed a high potential to produce biosurfactant.

Results: By using 165 rRNA sequence analysis, the bacterial isolates EMB16 and EMB21 were found to be closely related to Pseudomonas mendocina and Pseudomonas oleovorans, respectively. The ultimate yields of biosurfactant ( $8.06 \pm 0.06 \mathrm{mg} / \mathrm{ml}$ ) by Ps. mendocina EMB16 was with corn oil as a carbon source, urea as a nitrogen source, $\mathrm{C} / \mathrm{N}$ ratio of $30, \mathrm{pH}$ value of 7 , and $2 \%$ inoculum size. For Ps. oleovorans EMB21, the maximum biosurfactant production $(4.68 \pm 0.14 \mathrm{mg} / \mathrm{ml})$ was achieved by diesel oil as a carbon source, urea as a nitrogen source, $\mathrm{C} / \mathrm{N}$ ratio of 30, $\mathrm{pH}$ of 7, and 5\% size of inoculum. The best incubation period and temperature for the examined strains was $168 \mathrm{hrs}$. at $37^{\circ} \mathrm{C}$.

Conclusion: The results proved that Ps. mendocina EMB16 was the most efficient biosurfactant producer as it showed the greatest amount of biosurfactant concentration and lowest value of surface tension measurement with an emulsification index of $67 \pm 6 \%$.

Keywords: Surface-active agents, sequence analysis, carbon, nitrogen, Pseudomonas
\end{abstract}

\section{Introduction}

Microorganisms are able to biosynthesize secondary metabolite and they may play critical roles in their growth. Biological surface-active molecules are an example of such metabolites. Biosurfactant are of great importance for microorganisms' structural, functional diversity and broad-spectrum applications. ${ }^{1}$ Although Biosurfactant producing microorganisms were isolated from different environments, they were normally present in the oil debased soil. ${ }^{2}$ In such oil contaminated environment, biosurfactant production by microorganisms facilitate emulsification of the hydrocarbons. ${ }^{3}$ To isolate interesting biosurfactant producing microbes, effective screening analysis should be employed. Several authors have reported that a single screening method is insufficient to select excellent biosurfactant producers. ${ }^{4-6}$ The production of biosurfactant by microorganisms are depends on various factors such as carbon source, nitrogen source, carbon to nitrogen ratio, $\mathrm{pH}$, temperature, agitation, and oxygen availability. ${ }^{7}$ Diverse metabolic pathways are involved in the synthesis of precursors for biosurfactant production, and this depend on the nature of the main carbon sources employed in the culture medium. ${ }^{8}$ The current research aimed to investigate the effect of different nutritional factors and growth conditions on biosurfactant production by selected bacterial isolates EMB16 and EMB21 which isolated from oil-contaminated soil collected from southern seashores in Jeddah, Saudi Arabia.

\section{Methodology}

\section{Isolation and Screening}

To isolate biosurfactant producing bacteria, the enrichment method was applied using the procedure that described previously by Motwali et al., (2020). Number of quantitative and qualitative methods were used to screen the biosurfactant production ability of bacterial isolates. According to technique reported by Motwali et al., (2020), Drop collapse and CTAB assay was used as qualitative method, while oil displacement test and surface tension measurement was utilized as a quantitative one. ${ }^{9}$

\section{Morphological Characterization and Molecular Identification}

The morphological characterization and molecular identification of the purified selected bacterial isolates EMB16 and EMB21 were determined by using the method reported by Motwali et al., (2021). ${ }^{10}$

\section{Effects of Different Nutritional Factors and Growth Conditions on Biosurfactant Production}

A mineral salt medium containing $1 \%$ diesel oil as the sole carbon and energy source was used as a production medium. ${ }^{11}$ The structure of the used production medium was (g/l): 20 of $\mathrm{NaCl}, 2.0$ of $\mathrm{KH}_{2} \mathrm{PO}_{4}, 1.0$ of $\mathrm{NH}_{4} \mathrm{NO}_{3}, 3.0$ of $\mathrm{Na}_{2} \mathrm{HPO}_{4}, 0.7$ of $\mathrm{MgSO}_{4} \cdot 7 \mathrm{H}_{2} \mathrm{O}$. Then, one $\mathrm{ml} / \mathrm{l}$ of the trace element solution was added to the mineral salt medium. The trace element solution composition was (mg/L): $\mathrm{ZnSO}_{4} .7 \mathrm{H}_{2} \mathrm{O}, 10 ; \mathrm{CuSO}_{4} .5 \mathrm{H}_{2} \mathrm{O}, 0.50$; $\mathrm{MnSO}_{4} \cdot \mathrm{H}_{2} \mathrm{O}, 0.50 ; \mathrm{CaCl}_{2}, 20 ; \mathrm{FeCl}_{3}, 30$, after which the solution was adjusted to $\mathrm{pH} 7.0 .^{12}$ After that, the production medium was inoculated with $1 \%$ of selected bacterial subculture (bacterial OD was $1.34 \pm 0.02$ at $600 \mathrm{~nm}$ ). In order to examine the impact of nutritional factors on biosurfactant production, the production medium was supplemented with different carbon source (glucose, glycerol, corn oil, olive oil, sunflower oil, sesame oil, mustard oil, xylene, diesel, toluene, 
or lubricating oil), nitrogen sources (yeast extract, peptone urea, $\mathrm{NaNO}_{3}, \mathrm{KNO}_{3}$, or $\left.\mathrm{NH}_{4} \mathrm{NO}_{3}\right)$ at ratio of $\mathrm{C} / \mathrm{N}(10,20,30$, 40 or 50). Range of growth parameters were also investigated such as $\mathrm{pH}$ value $(3,5,7,9$ or 11$)$, temperature $\left(20-50^{\circ} \mathrm{C}\right)$, inoculum size $(0.5-7 \%)$, and incubation periods $(96,168,240$ or $312 \mathrm{hrs}$.). The concentration of the produced biosurfactant in bacterial supernatant was done indirectly by using orcinol assay by using the approach reported previously by Motwali et al., (2021). ${ }^{10}$

\section{Detection the Activity of the Produced Biosurfactant}

After incubating the chosen bacterial culture under proper nutritional factors and growth conditions, emulsification index (EI24) and surface tension measurement of bacterial supernatant were calculated. Emulsification index (EI24) was determined by applying the same procedure as described by Gagelidze et al., (2016). ${ }^{13}$ Surface tension measurement was done at room temperature using a tensiometer (Kruss Force K6).

\section{Statistical Analysis}

Statistical analysis was performed using the Statistical Package for Social Sciences version 24.0 for Windows (SPSS Inc., Armonk, NY, USA). Kruskal-Wallis test was carried out to identify a significant of responses to study nutritional factors and growth parameters.

\section{Result}

\section{Screening the Selected Bacterial Isolates for Biosurfactant Production}

The selected bacterial isolates EMB16 and EMB21 showed positive activity on qualitative screening methods CTAB assay and drop collapse test. Furthermore, they were able to spread the oil in an oil spreading test by more than $2.00 \mathrm{~cm}$ diameter as shown in (Figure 1a). Also, they were able to reduce surface tension to $<45 \mathrm{mN} / \mathrm{m}$ (Figure, $1 \mathrm{~b}$ ).

\section{Morphological Characterization and Molecular Identification}

The selected bacterial isolates EMB16 and EMB21 were characterised as an aerobic gram negative non spore forming bacteria. Molecular identification of the selected isolates was performed using the GenBank BLAST tool on the 16S rRNA gene sequences. The selected bacterial isolate EMB16 was closely related $(98.71 \%)$ to Pseudomonas mendocina under accession number MK 640833.1 whereas EMB21 was closely
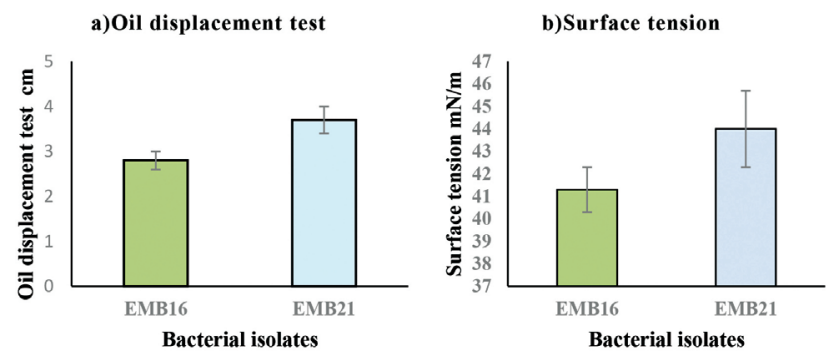

Fig. 1 a) Result of oil displacement test and b) Result of surface tension measurement of chosen bacterial isolates EMB16 and EMB 21. related (99.73\%) to Pseudomonas oleovorans with accession number MK078535.1 and phylogenetic trees are shown in Figures 2 and 3.

\section{Effects of Different Nutritional Factors and Growth Conditions on Biosurfactant Production}

The effect of different carbon sources on biosurfactant production by chosen strains Ps. Mendocina EMB16 (MK640833.1) and Ps. oleovorans EMB21 (MK078535.1) are shows in Table 1 and Figure 4. It is clear from table that corn oil provides the greatest significant amount of biosurfactant concentrations (7.85 $\pm 0.2 \mathrm{mg} / \mathrm{ml}$ ) by Ps. mendocina EMB16 (MK640833.1). Furthermore, the production of biosurfactant by Ps. Mendocina EMB16 was also significantly and sensitively increased with glycerol $(7.48 \pm 0.5 \mathrm{mg} / \mathrm{ml})$, glucose $(7.15 \pm 0.7)$ and olive oil

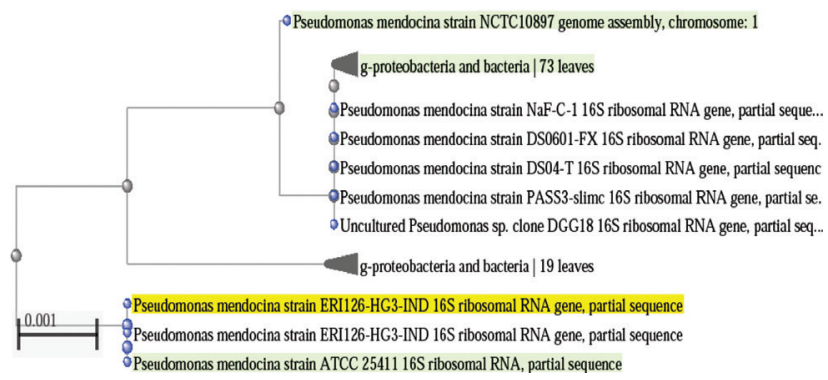

Fig. 2 The phylogenetic tree of Pseudomonas mendocina EMB16.

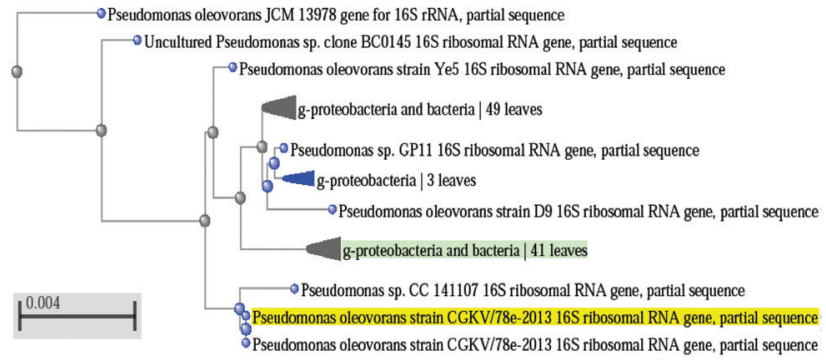

Fig. 3 The phylogenetic tree for Pseudomonas oleovorans EMB21.

Table 1. The effect of different carbon sources on biosurfactant (rhamnolipid) concentration produced by Ps. mendocina EMB16 and Ps. oleovorans EMB21

\begin{tabular}{lcc}
\hline Carbon source & Ps. mendocina EMB16 & Ps. oleovorans EMB21 \\
\hline Glucose & $7.15 \pm 0.7^{* \text { S3 }}$ & $3.45 \pm 0.2^{* 54}$ \\
Glycerol & $7.48 \pm 0.5^{* \text { S3 }}$ & $2.55 \pm 0.4^{\mathrm{S}}$ \\
Olive oil & $7.45 \pm 0.1^{* \mathrm{S3}}$ & $2.76 \pm 0.3^{\mathrm{S}}$ \\
Corn oil & $7.85 \pm 0.2^{* \text { S4 }}$ & $2.75 \pm 0.3^{\mathrm{S}}$ \\
Sunflower oil & $5.03 \pm 0.3$ & $1.77 \pm 0.3^{\mathrm{R}^{*}}$ \\
Sesame oil & $5.16 \pm 0.4^{\mathrm{R}}$ & $2.69 \pm 0.4$ \\
Mustard oil & $2.46 \pm 0.4^{\mathrm{R}^{*}}$ & $2.37 \pm 0.2^{\mathrm{R}}$ \\
Xylene & $1.99 \pm 0.2^{\mathrm{R}^{*}}$ & $1.44 \pm 0.03^{\mathrm{R}^{*}}$ \\
Diesel & $5.45 \pm 0.4^{\mathrm{S}}$ & $4.24 \pm 0.11^{* * 54}$ \\
Toluene & $2.04 \pm 0.3^{\mathrm{R}^{*}}$ & $1.53 \pm 0.14^{\mathrm{R}^{*}}$ \\
Lubricating oil & $1.95 \pm 0.3^{\mathrm{R}^{*}}$ & $1.53 \pm 0.2^{\mathrm{R}^{*}}$ \\
\hline
\end{tabular}

Highest value, ${ }^{*}$, Significant regard Kruskal-Wallis test; ${ }^{* *}$, Significant adjusted using Bonferroni; $\mathrm{S}$, Sensitive (increasingly affect); number above value $^{1-5}$, number of pairwise comparisons; $R$, Resistance (decreasingly affect). 


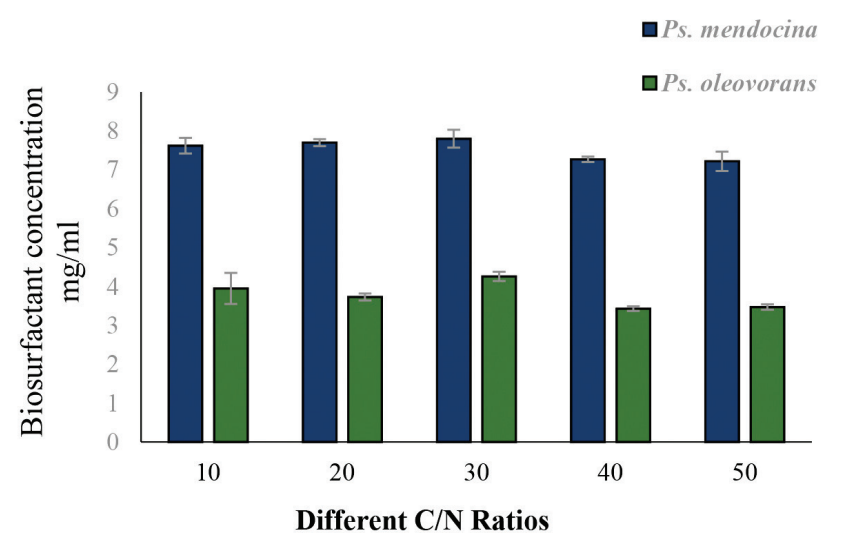

Fig. 4 The effect of different carbon to nitrogen ratio on biosurfactant (rhamnolipid) concentration produced by the two chosen Pseudomonas species.

(7.45 $\pm 0.1 \mathrm{mg} / \mathrm{ml})$. For Ps. Oleovorans EMB21 (MK078535.1), among different investigated carbon source diesel and glucose result in greatest significant biosurfactant concentration (4.24 \pm 0.11 and $3.45 \pm 0.2 \mathrm{mg} / \mathrm{ml}$ respectively). The amount of biosurfactant by examined Pseudomonas species with mustered oil, toluene, xylene and lubricating oil was significantly decreased.

After the selection of suitable carbon source for each examined bacterial isolates: Ps. mendocina EMB16 (MK640833.1) and Ps. oleovorans EMB21 (MK078535.1), the effect of different nitrogen sources on biosurfactant production were also investigated. The recorded result suggests that the highest biosurfactant concentration was noted with urea or ammonium nitrate $\mathrm{NH}_{4} \mathrm{NO}_{3}$ as a nitrogen source in the production media for all tested bacterial strains as shown in Table 2. Statically, biosurfactant production by Ps. mendocina EMB16 also was significantly improved with yeast extract, while with $\mathrm{NaNO}_{3}$ for Ps. oleovorans EMB21.

\section{Effects of Different C/N Ratios on Biosurfactant Production}

A suitable carbon source for each tested Pseudomonas species was added to the production media with different concentrations, along with a constant concentration of a selected nitrogen source (Urea). The greatest biosurfactant concentrations obtained by Ps. mendocina EMB16 $(7.80 \pm 0.07 \mathrm{mg} / \mathrm{ml})$ and Ps. Oleovorans EMB21 $(4.26 \pm 0.06 \mathrm{mg} / \mathrm{ml})$, were recorded at $\mathrm{C} / \mathrm{N}$ ratio of 30 (Figure 4 ). The result of statistical analysis showed that the $\mathrm{C} / \mathrm{N}$ ratio of 10 and 20 also lead to an increase in the production of biosurfactant by Ps. mendocina EMB16. Similar performance was observed for Ps. oleovorans EMB21 by $\mathrm{C} / \mathrm{N}$ ratio of 10 .

The $\mathrm{pH}$ of the production media for the tested Pseudomonas species was adjusted to different values. It is clear from Figure 5 that the highest significantly biosurfactant yield by the examined Pseudomonas species was at natural condition ( $\mathrm{pH} 7$ ) and the lowest was at acidic conditions ( $\mathrm{pH}$ of 3 ). For Ps. mendocina EMB16, the biosurfactant concentration was also significantly improved at $\mathrm{pH} 9$ whereas for Ps. oleovorans $\mathrm{EMB} 21$ at $\mathrm{pH} 5$.

After optimisation experiments for proper nutritional factors and $\mathrm{pH}$ value, the effect of incubation temperature also determined. The maximum significantly biosurfactant yield by $P$ s. mendocina EMB16 and Ps. Oleovorans EMB21 (MK078535.1) was $8.19 \pm 0.16$ and $4.07 \pm 0.10 \mathrm{mg} / \mathrm{ml}$, respectively, at $37^{\circ} \mathrm{C}$ (Figure 6). In addition, the production of

\begin{tabular}{lcc}
\hline $\begin{array}{l}\text { Table 2. The effect of different nitrogen sources on biosurfac- } \\
\text { tant (rhamnolipid) concentration produced by Ps. mendocina- } \\
\text { EMB16 and Ps. oleovorans EMB21 }\end{array}$ \\
\hline Nitrogen source & $\begin{array}{c}\text { Ps. mendocina } \\
\text { (EMB16) }\end{array}$ & $\begin{array}{c}\text { Ps. oleovorans } \\
\text { (EMB21) }\end{array}$ \\
\hline Yeast extract & $6.60 \pm 0.33^{* S 1}$ & $3.44 \pm 0.08^{\text {R* }}$ \\
Peptone & $6.18 \pm 0.22^{\text {R* }}$ & $2.20 \pm 0.13^{\text {R* }}$ \\
Urea & $8.06 \pm 0.05^{* * 53}$ & $4.44 \pm 0.11^{* * 54}$ \\
$\mathrm{NaNO}_{3}$ & $6.23 \pm 0.30^{\text {R* }}$ & $4.00 \pm 0.20^{* S 1}$ \\
$\mathrm{KNO}_{3}$ & $3.10 \pm 0.16^{\text {R* }}$ & $3.10 \pm 0.16^{\text {R* }}$ \\
$\mathrm{NH}_{4} \mathrm{NO}_{3}$ & $7.64 \pm 0.31^{* 51}$ & $4.26 \pm 0.23^{* 53}$ \\
\hline
\end{tabular}

Highest value, ${ }^{*}$, Significant regard Kruskal-Wallis test; ${ }^{* *}$, Significant adjusted using Bonferroni; S, Sensitive (increasingly effect); number above value $^{1-5}$, number of pairwise comparisons; R, Resistance (decreasingly effect).

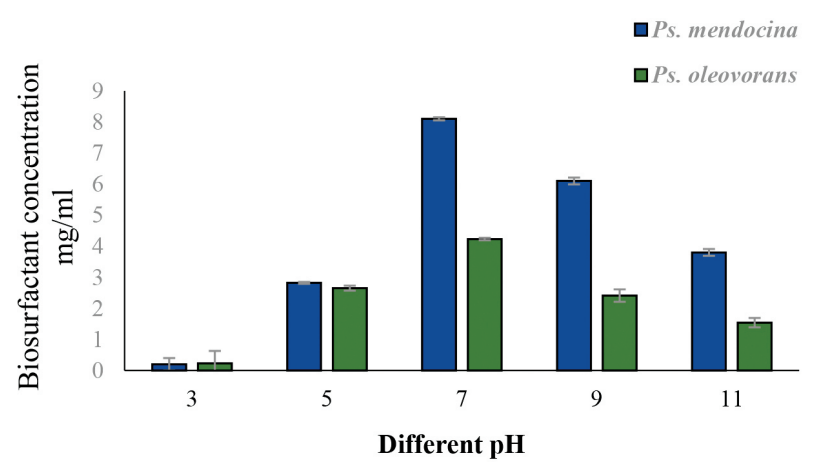

Fig. 5 The effect of changing pH on biosurfactant concentration produced by the two selected Pseudomonas species.

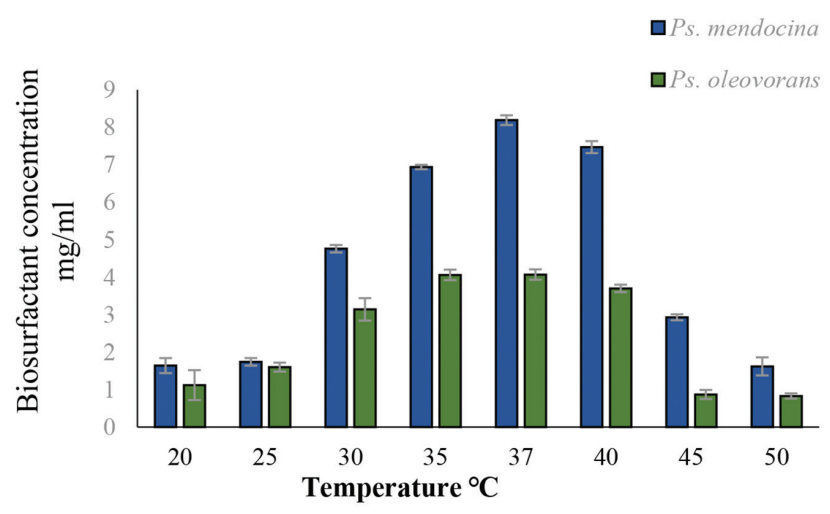

Fig. 6 The impact of different incubation temperature on biosurfactant concentration produced by the chosen Pseudomonas species.

biosurfactant by examined bacterial strains significantly augmented at temperatures of 35 and $40^{\circ} \mathrm{C}$.

Several inoculum size of Ps. Mendocina EMB16 and Ps. Oleovorans EMB21 were studied. The results represented in Figure 7 indicated that, the highest significantly biosurfactant production by Ps. mendocina EMB16 was $8.11 \pm 0.05 \mathrm{mg} / \mathrm{ml}$ was at $2.0 \%$ inoculum size. Moreover, the result of statistical analysis indicated that the biosurfactant yield at 1.0, 4.0 and $5.0 \%$ inoculum size were not significantly differed. Though, for Ps. oleovorans the best significantly biosurfactant yield was $4.84 \pm 0.23 \mathrm{mg} / \mathrm{ml}$ with $5.0 \%$ inoculum size. At inoculum size of 6 and $5 \%$, no significant differed was found. 


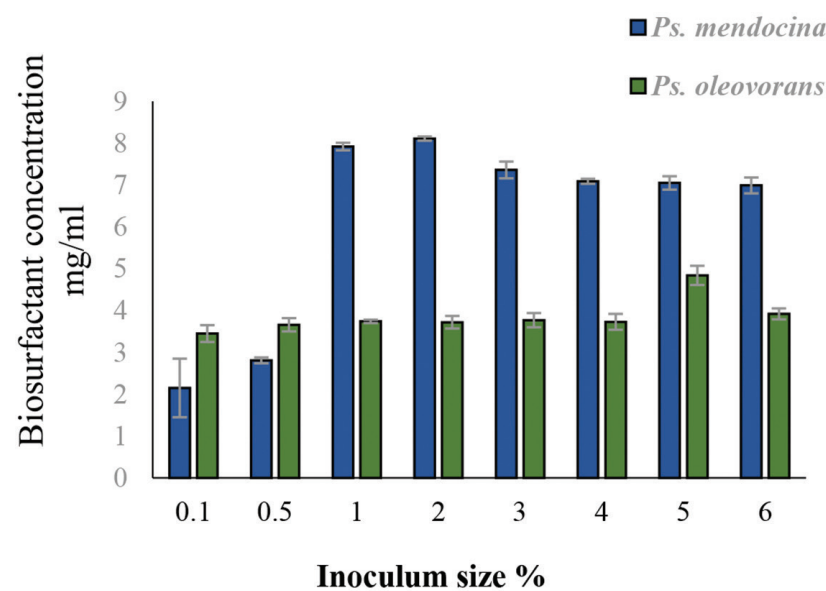

Fig. 7 The effect of different inoculum sizes on biosurfactant concentration produced by chosen Pseudomonas species.

The two tested bacterial strains Ps. mendocina EMB16 and Ps. oleovorans EMB21 were incubated for different time in the production medium with suitable selected nutritional factors and environmental parameter. The highest significantly biosurfactant amount by chosen Pseudomonas species, were at 168 hrs. or 7 days of incubation period (Figure 8). Furthermore, the lowest value of biosurfactant concentration for bacterial strains was observed at $96 \mathrm{hrs}$. of incubation period. The production of biosurfactant by Ps. oleovorans was maximum at 312 hrs. of incubation.

\section{The Activity of the Produced Biosurfactant}

The production media were prepared with selected nutritional factors and growth conditions for each bacterial strain Ps. mendocina EMB16 and Ps. oleovorans EMB21 (Table 3). After incubation period, the emulsification index EI24 and surface tension measurement for each bacterial supernatant Ps. mendocina EMB16 and Ps. oleovorans EMB21 were investigated. The result indicated that $P$ s. mendocina EMB16 recorded the lowest value $(31.6 \pm 0.6 \mathrm{mN} / \mathrm{m})$ in decrease the surface tension in comparison with Ps. oleovorans EMB21 $(42 \pm 1.0 \mathrm{mN} / \mathrm{m})$. For emulsification index EI24, Ps. mendocina EMB16 and Ps. oleovorans EMB21 were able to emulsify diesel oil by 67 and $60 \%$, respectively. It has been observed that the highest significantly biosurfactant concentration was reported for Ps. mendocina EMB16 $(8.06 \pm 0.06 \mathrm{mg} / \mathrm{ml})$ in comparison with $P$ s. oleovorans EMB21 $(4.68 \pm 0.14 \mathrm{mg} / \mathrm{ml})$. This finding suggested that Ps. mendocina EMB16 could produce large amount of biosurfactant (glycolipid), reduce the surface tension to less than $35 \mathrm{mN} / \mathrm{m}$ ) and emulsify diesel oil by more than $50 \%$. The statistically analysis indicates that Ps. mendocina EMB16 was the efficient biosurfactant producing Pseudomonas isolate.

\section{Discussion}

The present research was aimed to produce surface-active material from bacteria isolated from oil polluted samples. The oil contaminated soil samples were collected from southern shores of Jeddah city, Saudi Arabia. Isolation of bacteria which have capability to produce biosurfactant was done by enrichment culture method, which minimal medium was supplemented with hydrocarbon (diesel oil) as a sole carbon source. The selected bacterial isolates EMB16 and EMB21 have been

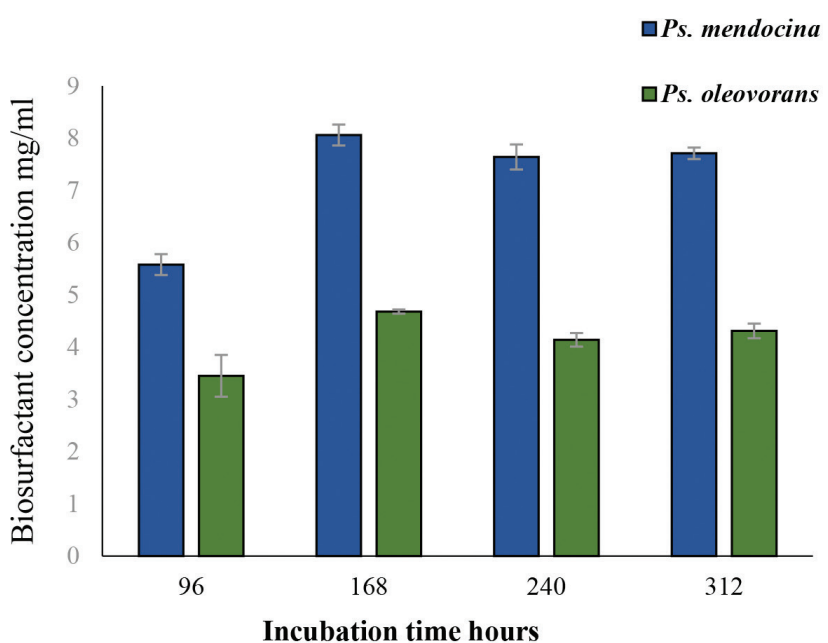

Fig. 8 The effect of different incubation time on biosurfactant (rhamnolipid) concentration produced by selected Pseudomonas species.

\begin{tabular}{lcc}
$\begin{array}{l}\text { Table 3. The best nutritional factors and growth conditions } \\
\text { for each tested Pseudomonas species, the amount of produced } \\
\text { biosurfactant, the recorded emulsification index and surface } \\
\text { tension value }\end{array}$ & $\begin{array}{c}\text { Ps. mendocina } \\
\text { EMB16 }\end{array}$ & $\begin{array}{c}\text { Ps. oleovorans } \\
\text { EMB21 }\end{array}$ \\
\hline Factor & Corn oil & Diesel oil \\
\hline Carbon source & Urea & Urea \\
Nitrogen source & 30 & 30 \\
C/N ratio & 7 & 7 \\
pH value & 37 & 37 \\
Temperature $\left({ }^{\circ} \mathrm{C}\right)$ & 2 & 5 \\
Inoculum size $(\%)$ & 168 & 168 \\
Incubation period (hrs.) & $8.06 \pm 0.06$ & $4.68 \pm 0.14$ \\
Yield of biosurfactant (mg/ml) & $31.6 \pm 0.6$ & $42 \pm 1.0$ \\
Surface tension ( $/ \mathrm{m})$ & $67 \pm 6$ & $60 \pm 8$ \\
Emulsification index \% & & \\
\hline
\end{tabular}

shown to be able to use hydrocarbons (diesel oil) as their sole carbon source. Supplementation of the isolation medium by hydrocarbon as a sole carbon source to isolate biosurfactant producing bacteria from oil contaminated environments was reported by many researchers. ${ }^{14-17}$

In terms of screening the biosurfactant producing ability of bacterial isolates EMB16 and EMB21, there are many distinct procedures that can be used, both qualitative and quantitative types. As reported by Satpute et al. (2008), more than one screening method should be used in the primary screening for the biosurfactant producers. ${ }^{4}$ In present study, dropcollapse test and CTAB agar assay as a qualitative investigates have been applied. As quantitative screening method, oil displacement test and surface tension measurement have been used. The bacterial isolates EMB16 and EMB21 in current study showed positive activity in the used qualitative methods this indicated they could be producing biosurfactant. Droplet collapses allow for speedy screening of a bacteria's efficacy as a biosurfactant producer. Mostly, this assay has been applied several times for screening purposes by many researchers. ${ }^{18-20}$ 
The Cetyltrimethylammonium bromide (CTAB) agar or blue agar assay is a specific screening method for anionic biosurfactants. It is used for the detection of glycolipid-type biosurfactant production by the bacterial colonies in the culture plate directly. ${ }^{21}$ In present investigation, dark bluish ring result that detected on CTAB agar by the supernatant of the bacterial isolates EMB 16 and EMB21 reveal the ability of anionic biosurfactant production by these selected bacterial isolates. This is in accordance with Nayarisseri et al., (2019) who found that 4 bacterial isolates belonging to Pseudomonas sp. and Bacillus sp. showed positive activity in CTAB test that confirmed existence of an anionic biosurfactant. ${ }^{22}$

The oil displacement test is a rapid quantitative method to test the presence of biosurfactant in the cell free culture broth. In addition, this method can detect even low activity and quantity of biosurfactant present. In this study, bacterial isolates EMB16 and EMB21 showed spreading the crude oil by more than $2.5 \mathrm{~cm}$ diameter. The result suggests the presence of biosurfactant. The present value of oil displacement test is lower than that obtained by Ibrahim, (2018) who detected a diameter $>5.0 \mathrm{~cm}$ of oil displacement test by screened bacterial isolates Ochrobactrum anthropi HM-1 and Citrobacter freundii HM-2. ${ }^{5}$ Oil displacement test was used often for biosurfactant production screening purpose by researchers. ${ }^{23,24}$

To further confirm the ability of bacterial isolates EMB16 and EMB21 to produce biosurfactant, the cell free culture broths of the selected isolates were subjected to surface tension measurement. Surface tension measurement is an important quantitative assay for evaluating surface activity of the tested isolates. The reduction in surface tension values achieved by the selected isolates EMB16 and EMB21 was $<45 \mathrm{mN} / \mathrm{m}$. This finding suggests the biosurfactant production ability by these examined isolates. In addition, the current value of surface tension was higher than that observed by Ahmad et al., (2016), Sun et al., (2018) and Ibrahim, (2018)..$^{5,14,25}$ They found a decrease in surface tension to less than $40 \mathrm{mN} / \mathrm{m}$ by different tested biosurfactant producing isolates.

Molecular identification for isolated bacteria was done by used 16S rRNA. Generally, 16S rRNA gene sequencing is an effective tool that has been used to identify bacteria and to find relationships between different bacterial genera. The $16 \mathrm{~S}$ rDNA sequence of the selected isolates EMB16 and EMB21 has been submitted to the Genbank database under the accession number MK640833.1 and MK078535.1, respectively. The results of $16 \mathrm{~S}$ rDNA sequence using the Genbank BLAST tool proved that the isolates EMB16 and EMB21 were belong to genus Pseudomonas. The bacterial isolate EMB16 showed 98.71\% similarity to Pseudomonas mendocina, while EMB21 showed $99.73 \%$ similarity to Pseudomonas oleovorans. Number of previous investigators used 16S rRNA gene sequencing to identify biosurfactant producing bacteria. ${ }^{15,16,26}$

The biosurfactant producing bacteria isolated from oil contaminated environment that belong to Pseudomonas sp. was reported by previous researchers. ${ }^{9,27-29}$ Commonly, bacterial isolates that belong to genus Pseudomonas are the greatest biosurfactant producers. ${ }^{30}$ There are not many studies about biosurfactant produce ability by Pseudomonas mendocina and Pseudomonas oleovorans. In contrary, different investigations study the production of biosurfactant from different Pseudomonas spices such as: Pseudomonas aeruginosa, ${ }^{31-33}$ Pseudomonas nitroreducens, ${ }^{34}$ Pseudomonas fluorescens, ${ }^{35}$ Pseudomonas putida ${ }^{36}$ and Pseudomonas balearica. ${ }^{10}$
Distinct nutritional factors and growth parameters were selected to investigate their effect on biosurfactant production by chosen isolates Ps. mendocina EMB16 and Ps. oleovorans EMB21. In the culture medium, carbon source played important role in increasing biosurfactant yield according to Noh et al., (2014). ${ }^{37}$ The significant highest yield of biosurfactant from Ps. mendocina EMB16 was $7.85 \pm 0.2 \mathrm{mg} / \mathrm{ml}$ with corn oil as a type of plant oil. On the other hand, the ultimate biosurfactant concentration $(4.24 \pm 0.11 \mathrm{mg} / \mathrm{ml})$ for Ps. Oleovorans EMB21 was observed with diesel oil. For Ps. mendocina same trend was observed by Pseudomonas sp. with plant oil as a carbon by researchers (Motwali et al., 2021 and Sun et al., 2021)..$^{10,38}$ Inversely, Onwosi and Odibo (2012) noted that the yield from diesel oil was higher than vegetable oil. ${ }^{39}$ The similar trend was observed with diesel oil as a carbon source in present study by Ps. oleovorans EMB21.

Since nitrogen sources play a vital role in the production of biosurfactant, effect of different nitrogen sources on biosurfactant production were studied. The current study found the highest significant biosurfactant concentration produced by Ps. mendocina EMB16 $(8.06 \pm 0.05 \mathrm{mg} / \mathrm{ml})$, and Ps. oleovorans EMB21 $(4.44 \pm 0.11 \mathrm{mg} / \mathrm{ml})$ were when urea was utilised as a nitrogen source in the production medium. As well, Ps. mendocina EMB16 and Ps. oleovorans EMB21 were able to produce higher biosurfactant concentration $(7.64 \pm 0.31$ and 4.26 $\pm 0.23, \mathrm{mg} / \mathrm{ml}$, respectively) with $\mathrm{NH}_{4} \mathrm{NO}_{3}$ among tested nitrogen sources. This in agreement with Motwali et al., (2021) who found that urea or $\mathrm{NH}_{4} \mathrm{NO}_{3}$ were the suitable nitrogen source for biosurfactant production by Ps. balearica. ${ }^{10}$ The present result also is agreeing with Alyousif et al., (2020) who found that urea was a best nitrogen source for biosurfactant production by $P$ s. aeruginosa..$^{40}$

The $\mathrm{C} / \mathrm{N}$ ratio also affects the production of biosurfactant by bacterial isolates. The highest biosurfactant production for the two examined Pseudomonas species (Ps. mendocina: $7.80 \pm 0.07$ and Ps. oleovorans: $4.26 \pm 0.06 \mathrm{mg} /$ $\mathrm{ml}$ ) were obtained at a $\mathrm{C} / \mathrm{N}$ ratio of 30 . At the $\mathrm{C} / \mathrm{N}$ ratio above 30, the bacterial isolate Ps. mendocina also recorded higher amount of biosurfactant. Less than $\mathrm{C} / \mathrm{N}$ ratio of 30 (around 20) was found to be suitable for biosurfactant production by members of Pseudomonas sp. ${ }^{41}$ In contrary, above $\mathrm{C} / \mathrm{N}$ ratio of 30 was observed to be proper for biosurfactant production by Ps. aeruginosa. ${ }^{42}$ Additionally, Prieto et al., (2008) proved that a nitrogen-limiting condition $(\mathrm{C} / \mathrm{N}$ ratio of 100$)$ was favorable to biosurfactant production by $P$ s. aeruginosa LBM $10 .{ }^{43}$

It is essential to define the suitable $\mathrm{pH}$ value for biosurfactant production by tested Pseudomonas isolates. The current research found that the best production of biosurfactant by Ps. mendocina EMB16 and Ps. oleovorans EMB21 was at $\mathrm{pH}$ 7. It is worth noting that, increasing the $\mathrm{pH}$ above 7 results in a decrease in biosurfactant production by the tested Pseudomonas isolates. This finding is approximately in the same trend with Sun et al., (2021), who found that the $\mathrm{pH}$ 7-8 was optimal for biosurfactant production by Pseudomonas sp. ${ }^{38}$ Also, they found $\mathrm{pH}>8$ and $\mathrm{pH}<7$ result in dropped in biosurfactant production by Pseudomonas sp. Similarly, maximum amount of biosurfactant from mutated strain of Bacillus subtilis was obtained at $\mathrm{pH} 7 .^{44}$ The result of present research is unagreed with Kannahi and Sherley (2012) who reported that a maximum level of biosurfactant production by Pseudomonas sp. was below $\mathrm{pH} 7 .^{45}$ 
Generally, optimization temperature has a significant impact on the enzyme activity and metabolic rate of the microbial isolates. In this investigation, the optimum temperature for maximum biosurfactant production by Ps. Mendocina EMB16 and Ps. Oleovorans EMB21 were $8.19 \pm 0.16$ and $4.07 \pm 0.10$ $\mathrm{mg} / \mathrm{ml}$, respectively at $37^{\circ} \mathrm{C}$. The bacterial isolates were also able to produce a high significantly biosurfactant concentration at temperature of 35 and $40^{\circ} \mathrm{C}$. The result of the current study is nearly in agreement with Yaraguppi et al., (2020) who found that the incubation temperature of $35-40^{\circ} \mathrm{C}$ resulted in a great biosurfactant yield by Bacillus aryabhattai strain ZDY2. ${ }^{46}$ Overall, increase in a temperature above $40^{\circ} \mathrm{C}$ led to decrease in biosurfactant yield by the two tested Pseudomonas isolates. Same trend was obtained previously by Soniyamby et al., (2011) for the biosurfactant production by Ps. aerogenesis. ${ }^{47}$

The inoculum size also plays important role in biosurfactant production by microbial isolates since it is related to the number of microbial cells in a used inoculum. Optimal inoculum size means optimal number of bacterial cells for bacterial reproduction and different bacterial activity. The present investigation obtained a great biosurfactant concentration by Ps. Mendocina EMB16 ( $8.11 \pm 0.05 \mathrm{mg} / \mathrm{ml})$, Ps. Oleovorans EMB21 $(4.84 \pm 0.23 \mathrm{mg} / \mathrm{ml})$ with inoculum size of 2.0 and $5.0 \%$, respectively. Silva et al., (2018) found that 3.0\% inoculum size was the best for biosurfactant. ${ }^{48}$ However, an inoculum size $4-5 \%$ was reported to be optimal for biosurfactant (rhamnolipid) production. ${ }^{49}$

The optimum incubation time for biosurfactant production by Ps. Mendocina EMB16 $(8.06 \pm 0.06 \mathrm{mg} / \mathrm{ml})$ and $P s$. Oleovorans EMB21 $(4.68 \pm 0.14 \mathrm{mg} / \mathrm{ml})$ was at $168 \mathrm{hrs}$. Nearly, the result herein agrees with the finding of Alyousif et al., (2020) who reported that the greatest biosurfactant concentration by Ps.aeruginosa was after $144 \mathrm{hrs}$. of incubation period. ${ }^{40}$ The present finding is contradicting the study of Devaraj et al., (2019) who found that the maximum yield obtained by Pseudomonas mosselii was at $96 \mathrm{hrs}^{50}$

After optimization the production medium, the surface tension of the culture supernatant of Ps. mendocina EMB16 and Ps. oleovorans EMB21 at the end of the incubation period
(169 hrs.) was $31.6 \pm 0.6$ and $42 \pm 1.0 \mathrm{mN} / \mathrm{m}$, respectively. Peekate and Abu (2017) recorded a surface tension value of $30.64 \mathrm{mN} / \mathrm{m}$ after optimization the production medium by Ps. fluorescens. ${ }^{35}$ Other than, Motwali et al., (2021) achieved a reduce in surface tension by Ps. balearica to $34 \mathrm{mN} / \mathrm{m}$ by using optimum nutrational and growth condition for biosurfactant production. ${ }^{10}$ The result of emulsification index EI $24 \%$ biosurfactant by Ps. mendocina EMB16 and Ps. oleovorans EMB21 showed emulsification activity by $\geq 60 \%$. This amount is higher than that reported by Abouseoud et al. (2008) who recorded an emulsifying activity of $49 \%$ by Ps. fluorescens with olive oil as the best carbon source. ${ }^{51}$ The highest biosurfactant concentration and the lowest surface tension value was achieved by Ps. mendocina EMB16 in present research. The statistically analysis indicates that, the Ps. mendocinawas significantly the efficient biosurfactant producing Pseudomonas isolates. It is worth mention that Ps. oleovorans although it showed activity on emulsification index $>50$ it recorded surface tension $>40$ with low biosurfactant (rhamnose sugar) concentration. So, Ps. oleovorans EMB21 could be able to produce a bioemulsifier beside biosurfactant. According to Uzoigwe et al., (2015), bioemulsifiers have emulsifying activity more than surface activity (lower the surface tension). ${ }^{5}$

\section{Conclusion}

The current research concludes that the nutritional factors and growth conditions play critical role in the biosurfactant production. The study proved that bacterium Ps. mendocina (EMB16) isolated from oil contaminated soil was efficient biosurfactant producing bacterium. It was remarked that corn oil as a carbon source, urea as a nitrogen source, $\mathrm{C} / \mathrm{N}$ ratio of 30 , $2 \%$ inoculum size at $37^{\circ} \mathrm{C}$ for $186 \mathrm{hrs}$. of incubation period provides the best biosurfactant production by Ps. mendocina EMB16. This Pseudomonas species can be employed further for larger biosurfactant production. Since the produced biosurfactant by Ps. mendocina EMB16 showed emulsifying and surface activity, it can be applied in bioremediation, in industrial and medical application.

\section{References}

1. Banat, I.M. and Thavasi, R. (2019) Microbial Biosurfactants and their Environmental and Industrial Applications. In: Introduction to Microbial Biosurfactant, Banat, I.M. and Thavasi, R. (editors), CRC Press, Boca Raton, Florida, 01-16.

2. Roy, A. (2017) Review on the Biosurfactants: Properties, Types and its Applications. Journal of Fundamentals of Renewable Energy and Applications, 8: 248-253.

3. Stroud, J.L.; Paton, G.l.; Semple, K.T. (2007) Microbe-aliphatic hydrocarbon interactions in soil; implications for biodegradation and bioremediation. Journal of Applied Microbiology, 102:1239-1253.

4. Satpute, S.K.; Bhawsar B.D.; Dhakephalkar, P.K. and Chopade, B.A. (2008) Assessment of different screening methods for selecting biosurfactant producing marine bacteria.Indian Journal of Marine Sciences, 37: 243-250.

5. Ibrahim, H.M.M. (2018) Characterization of biosurfactants produced by novel isolats of Ochrobactrumanthropi HM-1 and Citrobacter freundii HM-2 from used engine oil-contaminated soil. Egyptian Journal of Petroleum, 27: 21-29.

6. Adebajo, S.O.; Akintokun, P.O.; Ojo, A.E.; Akintokun, A.K. and Badmos, O.A. (2020) Recovery of biosurfactant using different extraction solvent by rhizospheric bacteria isolated from rice-husk and poultry waste biocharamended soil, Egyptian Journal of Basic and Applied Sciences, 7:1, 252-266.

7. Jahan, R.; Bodratti, A.M.; Tsianou, M. and Alexandridis, P. (2020) Biosurfactants, natural alternatives to synthetic surfactants: Physicochemical properties and applications. Advances in Colloid and Interface Science, 275: 22 pages.
8. Santos, D.K.F.; Luna, J.M.; Rufino, R.D.; Santos, V.A. and Sarubbo, L.A. (2016) Biosurfactants: multifunctional biomolecules of the 21st Century. International Journal of Molecular Sciences, 17(3):401-430.

9. Motwali, E.A.; Aly, M.M.; Qari, H. et al. (2020) Screening and Identification of Efficient Biosurfactant Producing Bacteria for some Medical Applications. La Prensa Medica Argentina, 2:005: 6.

10. Motwali, E.A.; Aly, M.M.; Qari, H.A.; Amasha, R.H. and Zabermawi, N.M. (2021) Effect of Growth Conditions on Biosurfactant Production by Pseudomonas balearica Isolated From Oil Contaminated Sea Waters from Jeddah Saudi Arabia. Bioscience Biotechnology Research Communication, 14(1): 9 pages.

11. Yalaoui-Guellal, D.; Brahmi, F.; Touati, A.; De Champs, C.; Banat, I.M. and Madania, K. (2017) Production of Biosurfactants by Hydrocarbons Degrading Bacteria Isolated from Soummam Watershed Sediments of Bejaia in Algeria Environmental Progress and Sustainable Energy, 37(1) 189-195.

12. Mao-Cheng, D.; Jing, L.; Fu-Rui, L.; Meisheng, Y.; Xiao-Ming, X.; Jian-Ping, Y.; Juan, P.; Chou-Fei, W. and Jiang-Hai, W. (2014). Isolation and characterization of a novel hydrocarbon-degrading bacterium Achromobacter sp. HZ01from the crude oil-contaminated seawater at the Daya Bay, southern China. Marine Pollution Bulletin, 83: 79-86.

13. Gagelidze, N.A.; Amiranashvili, L.L.; Varsimashvili, K.I.; Tinikashvili, L.M.; Lana, L.; Tolordava, L.L. and Sadunishvili, T.A. (2016) Selection of effective biosurfactant producers among Bacillus isolats isolated from soils of Georgia. Annals of agrarian science, (14): 72-75. 
14. Ahmad, Z.; Arshad, M.; Asghar, H.N.; Sheikh, M.A. and Crowley, D.E. (2016) Isolation, screening and functional characterization of biosurfactant producing bacteria isolated from crude oil contaminated site. International Journal of Agricultural and Biological Engineering, 18: 542-548.

15. Zainal, N.; Omar, S. and Ashaari, M. (2017) Isolation and Characterization of Biosurfactant-Producing Bacteria Isolated From Petroleum Contaminated Sites With The Potential To Be Used In Bioremediation. Science Heritage Journal, 1(2):11-15.

16. Soltanighias, A.; Singh, A.E.A.; Satpute, S.K.; Banpurkar, A.G.; Koolivand, A. and Rahi, P. (2019) Assessment of biosurfactant-producing bacteria from oil contaminated soils and their hydrocarbon degradation potential. Environmental Sustainability, 2: 285-296.

17. Channashettar, V.: Srivastava, S. and Lal B. (2020) Isolation and Characterization of Biosurfactant Producing Bacteria from Oil Sludge for Bioremediation of oil contaminated sites. International Journal of New Innovations in Engineering and Technology, 12: 063-041.

18. Krishnan, M., Subramanian, H., Dahms, H.U., et al., (2018). Biogenic corrosion inhibitor on mild steel protection in concentrated $\mathrm{HCl}$ medium. Scientific Reports, 8(1):1-16.

19. Oso, S.; Walters, M.; Schlechter, R.O. and Remus-Emsermann, M. (2019) Utilisation of hydrocarbons and production of surfactants by bacteria isolated from plant leaf surfaces. FEMS Microbiology Letters, 366 (6): 10 pages.

20. Wu, Y.; Xu, M.; Xue, J.; Shi, K. and Gu, M. (2019) Characterization and Enhanced Degradation Potentials of Biosurfactant-Producing Bacteria Isolated from a Marine Environment. ACS Omega, 4 (1):1645-1651.

21. Irorere, V.U.; Tripathi, L.; Marchant, R.; McClean, S. and Banat, I.M. (2017) Microbial rhamnolipid production: a critical reevaluation of published data and suggested future publication criteria. Applied Microbiology and Biotechnology, 101: 3941-3951.

22. Nayarisseri, A.; Singh, P. and Singh, S.K. (2019) Screening, isolation and characterization of biosurfactant-producing Bacillus tequilensis strain ANSKLAB04 from brackish river water. International Journal of Environmental Science Technology. 16: 7103-7112.

23. Gargouri, B.; Contreras, M.d.M.; Ammar, S. et al. (2017) Biosurfactant production by the crude oil degrading Stenotrophomonas sp. B-2: chemical characterization, biological activities and environmental applications. Environment Science and Pollution Research, 24: 3769-3779.

24. Dattaa, P.; Tiwaria, P.; Pandey, L.M. (2018) Isolation and characterization of biosurfactant producing and oil degrading Bacillus subtilis MG495086 from formation water of Assam oil reservoir and its suitability for enhanced oil recovery. Bioresource Technology, 270:439-448.

25. Sun, W.; Cao, W.; Jiang, M.; Saren, G.; Liu, J.; Cao, J.; Ali, l.; Yu, X.; Peng, C. and Naz, I. (2018) Isolation and characterization of biosurfactant-producing and diesel oil degrading Pseudomonas sp. CQ2 from Changqing oil field, China. Royal society of chemistry, 8: 39710-39720.

26. Elazzazy, A.M.; Abdelmoneim, T.S. \& Almaghrabi, O.A. (2015) Isolation and characterization of biosurfactant production under extreme environmental conditions by alkali-halo-thermophilic bacteria from Saudi Arabia. Saudi Journal of Biological Sciences, 22:466-475.

27. Joy, S.; Rahman, P.K. and Sharma, S. S. (2017) Biosurfactant production and concomitant hydrocarbon degradation potentials of bacteria isolated from extreme and hydrocarbon contaminated environments. Chemical Engineering Journal, 317: 232-241.

28. Varjani, S and Upasani, V.N. (2019) Evaluation of rhamnolipid production by a halotolerant novel strain of Pseudomonas aeruginosa. Bioresource Technology, 288: 6 pages

29. Zouari, O.; Lecouturier, D.; Rochex, A.; Chataigne, G.; Dhulster, P.; Jacques, P. and Ghrib, D. (2019) Bio-emulsifying and biodegradation activities of syringafactin producing Pseudomonas spp. isolates isolated from oil contaminated soils. Biodegradation, 30:259-272.

30. Sharma, D.; Ansari, M.J.; Al-Ghamdi, A.; Adgaba, N.; Khan, K.A.; Pruthi, V. and Al-Waili, N. (2015) Biosurfactant production by Pseudomonas aeruginosa DSVP20 isolated from petroleum hydrocarbon-contaminated soil and its physicochemical characterization. Environmental Science and Pollution Research, 22:17636-17643.

31. Liu, W.J.; Duan, X.D.; Wu, L.P. et al. (2018) Biosurfactant Production by Pseudomonas aeruginosa SNP0614 and its Effect on Biodegradation of Petroleum. Applied Biochemistry and Microbiology, 54: 155-162.

32. De Anchieta Câmara Jr, A., Maréchal, P. A., Tourdot-Maréchal, R., \& Husson, F. (2019). Oxidative stress resistance during dehydration of three nonSaccharomyces wine yeast strains. Food Research International, 123:364-372.
33. Conceição, K.S.; Almeida, M.; Sawoniuk, I.C. et al. (2020) Rhamnolipid production by Pseudomonas aeruginosa grown on membranes of bacterial cellulose supplemented with corn bran water extract. Environmental Science and Pollution Research, 27:30222-30231.

34. De Sousa, T. and Bhosle, S. (2012) Isolation and characterization of a lipopeptide bioemulsifier produced by Pseudomonas nitroreducens TSB. MJ10 isolated from a mangrove ecosystem. Bioresource Technology, 123: 256-262.

35. Peekate, P. L. and Abu, G. O. (2017) Optimizing C:N Ratio, C:P Ratio, and $\mathrm{pH}$ for Biosurfactant Production by Pseudomonas fluorescens. Journal of Advances in Microbiology, 7(2): 1-14.

36. Janeka, T.; Łukaszewicz, M. and Krasowska, A. (2013) Identification and characterization of biosurfactants produced by the Arctic bacterium Pseudomonas putida BD2. Colloids and Surfaces B: Biointerfaces, 110: 379-386.

37. Noh, N.A.; Salleh, S.M. and Yahya, A.R. (2014) Enhanced rhamnolipid production by Pseudomonas aeruginosa USM-AR2 via fed-batch cultivation based on maximum substrate uptake rate. Letters in Applied Microbiology, 58:617-623.

38. Sun, W.; Zhu, B.; Yang, F.; Dai, M.; Sehar, S.; Peng, C.; Ali, I. and Naz, I. (2021) Optimization of biosurfactant production from Pseudomonas sp. CQ2 and its application for remediation of heavy metal contaminated soil. Chemosphere, 265: 12 pages.

39. Onwosi, C.O. and Odibo, F.J.C. (2012) Effects of carbon and nitrogen sources on rhamnolipid biosurfactant production by Pseudomonas nitroreducens isolated from soil. World Journal of Microbiology \& Biotechnology, 28:937-942.

40. Alyousif, N.A.; Al-Tamimi, W.H. and Al-Luaibi, Y.Y.Y. (2020). Screening enhance production and characterization of biosurfactant produced by Pseudomonas aeruginosa isolated from hydrocarbon contaminated soil. Eurasian Journal of Bioscience, 14: 4377-4391.

41. Hassan, M., Essam, T., Yassin, A.S. and Salama, A. (2016) Optimization of rhamnolipid production by biodegrading bacterial isolates using PlackettBurman design. Int J Biol Macromol 8, 573-579.

42. Sharma, S.; Datta, P.; Kumar, B.; Tiwari, P. and Pandey, L.M. (2019b). Production of novel rhamnolipids via biodegradation of waste cooking oil using Pseudomonas aeruginosa MTCC7815. Biodegradation, 30:301-312.

43. Prieto, L.M.; Michelon, M.; Burkert, J.F.M.; Kalil, S.J. and Burkert, C.A.V. (2008) The production of rhamnolipid by a Pseudomonas aeruginosa strain isolated from a southern coastal zone in Brazil. Chemosphere, 71:1781-1785.

44. Asgher, M.; Afzal, M.; Qamar, S.A. et al. (2020) Optimization of biosurfactant production from chemically mutated strain of Bacillus subtilis using waste automobile oil as low-cost substrate. Environmental Sustainability, 3: 405413.

45. Kannahi, M. and Sherley, M. (2012) Biosurfactant production by Pseudomonas putida and Aspergillus niger from oil contaminated site. International Journal of Chemical and Pharmaceutical Sciences, 3(4): 37-42.

46. Yaraguppi, D.A.; Bagewadi, Z.K.; Muddapur, U.M. and Mulla, S. (2020) Response surface methodologybased optimization of biosurfactant production from isolated Bacillus aryabhattai strain ZDY2. Journal of Petroleum Exploration and Production Technology, 10:2483-2498.

47. Soniyamby, A.R.; Praveesh, B.V.; Vimalin, H.; Kavithakumari, P.; Sundaram, L. and Palaniswamy, M. (2011) Enhanced Production of Biosurfactant from Isolated Pseudomonas Sp. Growing on Used Edible oil. Journal of American Science, 7(6): 50-53.

48. Silva, E.J.; Correa, P.F.; Almeida, D.G.; Luna, J.M.; Rufino, R.D. and Sarubbo, L.A. (2018) Recovery of contaminated marine environments by biosurfactantenhanced bioremediation. Colloids and Surfaces B: Biointerfaces, 172:127-135.

49. Neto, D.C.; Meira, J.A.; Tiburtius, E.; Zamora, P.P.; Bugay, C.; Mitchel, D.A.; Krieger, N. (2009) Production of rhamnolipids in solid-state cultivation: Characterization, downstream processing and application in the cleaning of contaminated soils. Bioethanol Journal, 4(5):748-755.

50. Devaraj, S.; Sabapathy, P.C.; Nehru, L. and Preethi, K. (2019) Bioprocess optimization and production of biosurfactant from an unexplored substrate: Parthenium hysterophorus. Biodegradation, 30: 325-334.

51. Abouseoud, M.; Maachi, R.; Amrane, A.; Boudergua, S. and Nabi, A. (2008) Evaluation of different carbon and nitrogen sources in production of biosurfactant by Pseudomonas fluorescens. Desalination, 223: 143-151.

52. Uzoigwe, C.; Burgess, J. G.; Ennis, C. J. and Rahman, P. K. (2015) Bioemulsifiers are not biosurfactants and require different screening approaches. Frontiers in microbiology, 6: 245-251. 